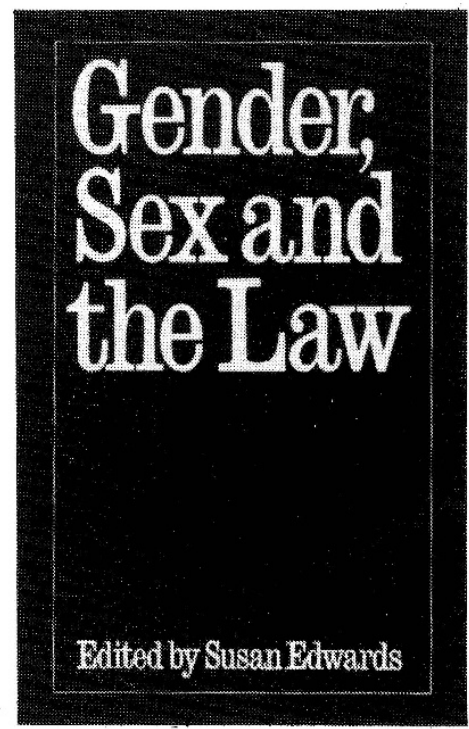

Gender, Sex and the Law Susan Edwards (ed)

Croom Helm London, 1985

ISBN $0709909381 £ 16.95$

The law's deep-rooted and historical complicity with women's inequality has long been a matter of concern to feminists, both in their struggles for progressive reforms of the law, and in their attempts to use existing provisions to women's advantage. This collection of papers both exemplifies this concern and explores some of the problems that are involved. In a wide-ranging series of articles, the authors describe a variety of 'interfaces' between women and the legal system, and examine some of the legal problems women face, whether as litigants, defendants, or simply as female subjects of the law, confronted by its current constraints. The picture presented is bleak: in almost all of the areas addressed, the legal system is portrayed as effectively excluding women from lawful rights and protections, as obstructing women's claims to social and economic equality, as enforcing or reinforcing traditional feminine roles, and as perpetuating women's existing disadvantages.
What is particularly sobering is the sheer variety of levels at which obstacles can be raised against women's attempts to make use of the law. Sometimes, as in the case of the immigration laws discussed by the Women, Immigration and Nationality Group, women face discrimination even at the level of the formal content of the law, which explicitly refuses to grant them the same rights as are accorded to men. More often, however, women find themselves disadvantaged by laws which are ostensibly genderneutral, but which make no adequate allowance for the different conditions under which men and women characteristically live, and which therefore cannot in practice be applied symmetrically. As Peggy Kahn makes clear in her paper on women and employment, this is painfully true even of the Sex Discrimination and Equal Pay Acts. Although this legislation was initially construed as a major step towards the eradication of sexual inequalities, it is clear that in practice it 'neither adequately protects women where they manage to work nor creates significant new opportunities for women to enter employment' (p.95).

At this level, various of the papers identify areas where women could usefully press for changes in legislation. But what is also clear from these papers is that no amount of tinkering with the formal provisions of the law can ultimately guarantee against sexual bias in its application and interpretation. At the level of interpretation, there are illustrations throughout the book of cases where potentially progressive or at least neutral laws are interpreted (often with apparent perversity) in such a way as to deny women legal access to rights or legal redress of wrongs. In the context of employment law discussed by Judith Mayhew, for example, industrial tribunals have refused to interpret pregnancy as a 'medical condition' an interpretation which would have 
allowed women to claim the same legal protections during pregnancy leave as are accorded to workers absent owing to illness. In sharp contrast, however, is the legal interpretation when women seek protection against unwanted medical interference in their pregnancies. Here, as discussed in a conceptually and politically very different paper by Beverley Beech, legal agents have consistently chosen to view pregnancy as an inherently medical condition, whose proper treatment can only be determined by clinical judgement. By this tactic pregnant women are excluded not only from decisions about the conduct and circumstances of the birth, but also from legal redress against forms of violent medical coercion that might otherwise be construed as serious criminal assault. Finally, women face discrimination at the level of the enforcement of the law. This problem is illustrated in Susan Edwards's two papers, which deal with legal discretion in the protection of victimized women and in the sentencing of female offenders. In both cases she depicts the systematic disadvantaging of women, along with the more or less coercive reinforcement of traditional inequalities and divisions.

In assembling this kaleidoscopic variety of material in a single volume, there is an understandable desire to knot the various strands together within some unifying conceptual framework. This Susan Edwards attempts to do in her introductory thesis, through the assertion that in relation to the law, 'women's special status and women's debilitated status stem from a common ideology, from a belief in an essentialist biological and physiological incapacity which spans not only assessment of physical capability but also mental capacity' (p.1). She backs this argument largely by reference to the now familiar archive of Victorian discourses on female incapacity, glossing over a century of legal reforms and transformations with the assertion that 'despite certain progress women's exclusion, exemption, differential or special treatment remains predicated on anatomical differences and the assumption that certain gender roles are incumbent on this essentialist criterion' (p.7). This formulation is appealingly neat and tidy, but actually does nothing to unify the discussions that follow, and indeed seems to bear little relation to many of them. Simply at a factual level, the claim of a uniform judicial essentialism seems highly debatable, and is not consistently borne out even by the material presented in the book itself. As illustrated in Katherine O'Donovan's paper on transsexualism, for example, the interpreters of the law seem rather to lack a consistent approach to gender, adopting biological criteria to categorize transsexuals as one sex for certain purposes, but nonbiological criteria to categorize them as the opposite sex for others. More importantly, Edwards's concerted attack on legal biologism as a matter of principle' actually serves to obscure some of the most interesting issues that emerge from these discussions. In the first place, it implies that there is a homogeneous domain of women's interests, in which the appeal to female biology could be construed as homogeneously harmful. But as is hinted in several of the papers, and made quite explicit in Linda Luckhaus's 'Plea for PMT in the Criminal Law', what will count as 'women's interests' is contextually variable, and there are certainly occasions when the deployment of biological arguments can operate very much in women's favour. At the same time, Edwards's position has the effect of over-emphasizing the practical importance of 'arguments in principle' in relation to the achievement of particular legal objectives. For one of the most politically challenging aspects of this collection is its demonstration of the extent to 
which both the advancement and the obstruction of feminist objectives within the law is dependent upon tactical manoeuvres, utilizing whatever arguments are expedient, and frequently producing results which are politically problematic and conceptually untidy. This is brought out most clearly and explicitly in a fascinating paper by Susan Maidment, who explores the highly compromising arguments that women find themselves putting forward in their claims to privileged rights in the care and custody of their biological children.

At the opening of the book, Edwards describes it as a 'collection of discussion papers' and it is to be hoped that it is on these terms that it will be read and used - as a preliminary introduction to a series of difficult areas and problems, and as a basis for further work. For although it is almost certain to find a ready readership within both women's studies and the sociology of law, it is not a textbook, and neither provides a general overview of the field nor advances any integrated analysis. In this sense, Edwards's attempts at a theoretical unification are merely misleading: what are possibly the most valuable (even if largely unintended) contributions of the book are its exposure of the fragmentation of the legal field itself and its uncomfortable demonstration of the problems that this imposes for feminist work within it.

Hilary Allen

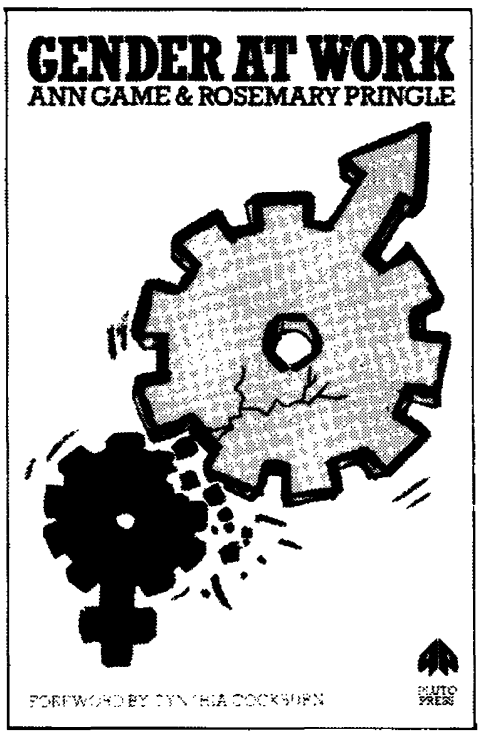

\section{Gender at Work}

\section{Ann Game}

and Rosemary Pringle

Pluto London, 1984, 145pp.

ISBN $0861046714 £ 3.95 \mathrm{Pbk}$

Gender at Work arrived in Britain as a highly recommended book. Imported from Australia, where it was acclaimed, it is packaged in its
British edition with a warm introduction by Cynthia Cockburn and a strong statement of endorsement on the cover from Ursula Huws. So, I too want to add my voice to the chorus: this is indeed an important book. Apart from its other achievements, it offers a complex handling of the concept of skill. In particular, it represents a systematic refutation of a monolithic deskilling thesis. Within a framework which posits gender relations as integral rather than functional to the operations of capitalism, the authors examine a range of industrial and labour processes. So I might begin my song of praise.

However, at the risk of dissidence or, perhaps, dissonance, I want to strike a slightly different note and venture some reservations about the text. But let me begin by describing the book.

It derived from Ann Game's and Rosemary Pringle's participation in the Women's Employment Rights Campaign (WERC), launched in Australia in 1977 in the face of the growth in female unemployment and media efforts to blame women 